ment of provisions and supervision of cleaning and nursing duties. The hospital committee considered that they could not "too strongly impress upon him the necessity of politeness to all visitors" whom he was expected to escort around the ship.

Only the chief nurse was required to read. All nurses were responsible for the cleanliness of the wards, and at night one of them kept watch and reported any change in a patient's medical condition to the resident medical officer. As the Hamadryad was a wooden frigate nurses were to stop nails being driven into any part of the wards and to prevent smoking or the carrying of naked lights. The upper nurse looked after the half-ports, which were opened only with the permission of the medical officer. Nothing was to be thrown out of these ports or passed in to patients through them. The rules applying to the social life of nurses were strict. They were allowed ashore only for the night when leave was granted and had to return by 6 am in summer or 7 am in winter. ${ }^{4}$

The cook, who had to "be clean in his person, and keep the galley and cooking utensils in perfect order and cleanliness," was expected to present a sample of his cooking at each meal to the medical officer for inspection.

By 1897 the inadequacy of the accommodation on the ship was recognised. Deterioration in the structure of the ship and defective sanitation compared poorly with that in the Union
Hospital. During its 30 years, however, 173000 patients from all over the world were treated on the ship: 1285 had fractures or dislocations, 1384 wounds, and 2098 chest infections. Of the 1182 fever cases, many came from the town itself. Alderman Beavan, the Mayor of Cardiff, convened a meeting to discuss the best means of celebrating the Diamond Jubilee of Queen Victoria and suggested that a permanent seamen's hospita should be built. It was opened on 29 June 1905 and as the Royal Hamadryad Seamen's Hospital continued to provide free medical treatment for seamen until 1948, when it was incorporated into the National Health Service.

I thank Dr Ralph Marshall and Mr Paul Crompton for help in preparing the illustrations.

\section{References}

${ }^{1}$ McBride AG. The History of the Dreadnought Seamens Hospital at Greenwich. Greenwich: Seamens Hospital Management Committee, 1970.

${ }^{2}$ Cardiff Times 1866 March 2.

${ }^{3}$ Cardiff and Merthyr Guardian 1866 March 9.

4 "Hamadryad"'Seamen's Hospital Rules. Cardiff: Lewis and Williams, 1868

(Accepted 5 May 1980)

\title{
Pages from a diary
}

\section{ELSTON GREY-TURNER}

In the autumn of 1943 the 2nd Battalion Coldstream Guards (of which I was the medical officer) was in reserve in Algeria after the North African campaign and the capture of the Italian islands of Pantelleria, Lampedusa, and Sicily. We were suddenly selected for an unusual mission. The commanding officer was ordered to take half the battalion east to a secret map reference near Tunis. We drove at high speed through well-remembered places: Souk-el-Arba, Beja, Gascape Hill, Coldstream Hill, Medjez-el-Bab, Furna, and Massicault. At the ordained rendezvous, a military police officer gave the $\mathrm{CO}$ further sealed orders to proceed at full speed to another secret destination, which we reached in the evening. My diary recorded:

4 December 1943. We surround a "white house" where certain big chiefs (?Churchill, Roosevelt, Stalin) are to meet shortly. We are to take incredible security precautions. The regimental aid post is in the cellar of a house. It is lovely to be in Tunis again, warm, by the sea.

The "white house" was a large and beautiful villa at sea level on the Gulf of Tunis. It was completely hidden on the landward side but was overlooked by another villa (where were battalion headquarters and one company), by an old fort in which Major Henry Green and his company were established, and by a tented camp, where the rest of the battalion was quartered. The whole area was completely enclosed by two barbed wire entanglements, heavily guarded by the battalion. The main gate was manned by American military police. Off shore, a naval picket boat cruised up and down.

\section{Petersham, Surrey}

ELSTON GREY-TURNER, MA, MD, formerly Secretary, BMA

\section{My diary again:}

6 December. Carthage. This is really the most delightful change and rest. I'm sitting on the balcony of our villa in the afternoon sun looking over the blue Gulf of Tunis. Beneath me is the lovely villa we are to guard. On the right is Henry Green's fort. In the distance is the dear old Zaghouan,* and over the gulf are Hamman Lif and the Kournine. $†$ It is tremendous joy being back here.

This morning, after seeing the sick, I went with the ambulance into Tunis with a patient, and bought large quantities of fruit, wine, etc for the battalion. Tunis looked as full as ever, but not so gay.

Lovely heat at midday. I'm running a sweepstake on who comes to the white house.

To dinner came the two American colonels in charge of security here. Very charming and sensible senior American officers.

The sweepstake was a huge success, although some of the fifty-odd runners (such as the Emperor of Japan) were considered to be outsiders.

\section{Arrival of President Roosevelt}

7 December. $\quad$ D day. Lovely hot morning. I have a bathe each day before breakfast, very refreshing though cold.

At about 1400 the battalion mounted all the guards and the airfield party reported there for duty. At 1530 three big planes flew in escorted by 16 fighters. At 1600 the notables arrived at the white house in a fleet of cars. We identified President Roosevelt, his son, General Eisenhower, and Mr Hopkins.

There were a lot of callers at the white villa on this lovely moonlit evening.

*The highest mountain of Tunisia, visible from many of the battlefields. †Another mountain. 
8 December. We all got up at dawn, and a guard of honour was mounted for President Roosevelt. The rest of us lined the drive of the villa. At 0730 he left and stopped at Bill Harris's guard of honour (the drums played four bars of the regimental march) and thanked the commanding officer for it. The President and Eisenhower were obviously very pleased. We had a good view as they drove away.

Shopped in Tunis in the morning. After lunch the battalion was ordered to mount guards again, and at tea-time the whole party returned. We wonder why.

The explanation was that the President, after inspecting American troops in Sicily, had intended to fly to the USA but was prevented by bad weather. I vividly remember that President Roosevelt had to be lifted bodily from his car to the villa and vice versa. His poliomyelitis had left him much more handicapped than was apparent from his published photographs.

10 December. Anniversary of our march into Medjez. A quiet day here, damp. Visited Tunis in the morning with a patient. We are still "gated" because there is a likelihood of further notabilities arriving.

\section{Arrival of Mr Churchill}

11 December. At about 0900 there arrived at the white villa, Churchill, his daughter Sarah, his son, General Sir Alan Brooke, Air Marshal Tedder, Lord Moran, etc, etc. Also Eisenhower again.

After tea came Colonel Boyle with Francis Brown of the PM's party to drinks. The latter was at Trinity with me, then Scoones, then Foreign Office, then Coldstream, then PM's secretary (which he now is). They said the PM was in good form and had just "pulled it off" at the recent conferences.

The Big Three had met at Teheran, after which Mr Churchill had had a meeting with the Turkish president. We were not told what Winston had just "pulled off," but we suspected it might be Turkish participation against Germany. This surmise is borne out by the detailed descriptions of the Teheran Conference, and of the Prime Minister's stay at Carthage, in volume V of The Second World War by Winston Churchill.

Scoones was the well-known training establishment in London for the Diplomatic Service. I had worked there for a few fascinating months in 1939 under that amazingly forceful personality and trainer of many generations of diplomats, Monsieur Andre Turquet, whose son Pierre became a psychiatrist.

Sunday 12 December. Another quiet day, fine but windy. After tea Lieutenant Hinchliffe of the US Provost Corps came in for a few drinks and told us General Eisenhower's views about the French, and then to dinner came Colonel Connally again. $\mathrm{He}$ was in good form and told us about Eisenhower sacking the waiters at the white villa yesterday.

General Alexander arrived to-day.

The white house was the Supreme Commander's villa, and it appeared that he had been displeased with the American Army waiters who were employed there. In a rage he ordered them all to be sent back to Algiers in a Flying Fortress and a new staff to be brought up. This was done.

13 December. Rumour that Churchill is ill in the white house. Strong wind to-day. I had to go to Tunis morning and afternoon on various errands for the battalion.

14 December. Howling gale to-day, and rain. This evening with Petre Crowder called at a house where I had attended the little son ten days ago, and the father showed me his chemical laboratory where he makes perfumes. Very interesting. He gave me a bottle of scent.

General Jumbo Wilson at the white house to-day.

This chemist supplied perfumes to the firm of Colgate's, whose shaving cream I used. The scent in my tube of shavingcream had, therefore, come back to its point of origin, via England!

15 December. Another damp windy day. The PM is ill, and we hear to-night that we shall be here another week at least. 16 December. On the British wireless news today there were the first two bulletins re Churchill's health. Pneumonia of left lung, North Africa (no indication where). Making progress. Bulletin signed by Lord Moran and by a brigadier and a lieutenant-colonel, consultants to Middle East Forces.

We gather he is fairly ill. The weather is still bad. Throughout his visit, the battalion has kept two ceremonial sentries on the door of the white house, who do their job well and are the admiration of everyone, especially the Yanks.

17 December. Commanding officer flew back to Constantine today and saw the rear party. Says the brigadier does not look well. 18 December. Francis Brown and Jock Colville, now returned as private secretary to the PM, came in for a drink this evening. The PM is better.

Sunday, 19 December. Better weather today, though the gale still blows. After tea some of us were invited down to the white house to see a film. We were received by Sarah (in WAAF uniform) and Randolph, who looks appallingly old and faded, and had drinks. I had a talk with Lord Moran, who was writing a report on the PM's illness (? for the King), and with Jock Colville. Then we saw the film "Crazy Gang" (Olson and Johnson), which was quite amusing. Inspector Thompson and the other Yard man were there. I caught a glimpse of Mrs Churchill before the film.

Afterwards we went back into the big hall for drinks. I had a long talk with Brigadier Evan Bedford (medical consultant, MEF). I gathered the PM had a fairly narrow squeak, and he didn't seem too happy about Churchill's health in the future. $\mathrm{He}$ is apparently a difficult patient. Colonel Connally called in, also the WAAC officer who acts as housekeeper there.

Brigadier Bedford was very interested in all my professional experiences in the BNAF. He introduced me to LieutenantColonel Pulvertaft, also attending the PM.

In The Second World War Churchill wrote: "I did not feel so ill in this attack as $I$ had the previous February. The $M$ and $B$, which I also called Moran and Bedford, did the work most effectively."

20 December. Bill Harris conducted Mrs Churchill and party round the Medjez battlefields after lunch. Petre Crowder and I went for a very enjoyable walk round Sidi Bou Said.

The Africa Star ribbons arrived today.

Major-General Eveleigh arrived this evening (he is now commanding 6th Armoured Division) to take over command of the defences of the white villa. There is apparently a flap in high circles because the Germans are thought to know that Churchill is here.

The "flap" was not unjustified. The spectacular kidnap or rescue of Mussolini by Scarface Skorzeny and his parachutists had lately taken place, and some attempt to capture or kill $\mathrm{Mr}$ Churchill was by no means outside the bounds of possibility. General Eveleigh brought with him a motorised company of the Rifle Brigade, a squadron of tanks, and a battery of anti-aircraft guns to reinforce the garrison of the white house.

24 December. Am writing from my bed. Have been sickening for a day or two, I fear for jaundice.

The PM is still in bed. We have the Welsh Guards' padre with us now, also a company of Rifle Brigade and some 17th/21st boys. Christmas Day. Attended early service in Henry's fort today. Two nations and twelve British units were represented. The service went very well, and was helped by birds twittering in the roof, by a dove flying in at the right moment, and by the great bell of Carthage starting to toll at the end. A happier Christmas morning than last year! 


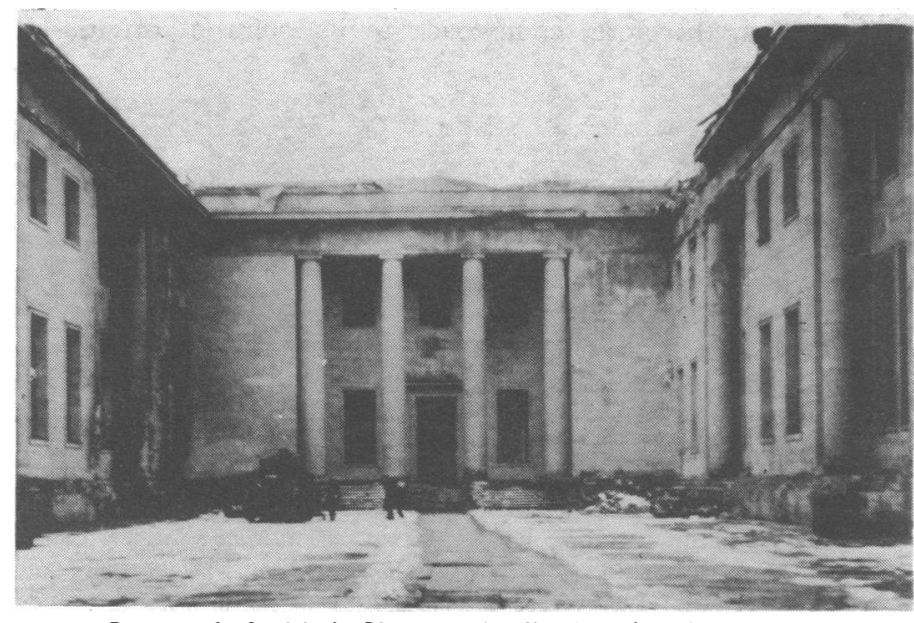

FIG 1-Courtyard of Hitler's Chancery, Berlin, March 1946.

During the morning many British and American officers came with greetings to our villa. There were of course a great many important callers at the white house, including General Jumbo Wilson, Admiral Cunningham (not Andrew B),* Air-Marshal Tedder, General Eisenhower, and General Mast.

We hear today that Eisenhower is appointed C-in-C of the cross-Channel invasion, with Monty under him. Jumbo gets the Mediterranean theatre and Alexander gets Italy.

Before dinner Brigadier Hollis (secretary to Chiefs of Staffs Committee), John Martin (secretary to PM), and Major Morton (of the Treasury) came up for a drink, and were very interesting.

After dinner the commander, company commanders, padre, and myself went down to drinks and supper at the white house. There were many notabilities there, including Jumbo, Alexander, Cunningham, Harold Macmillan, and many other officers. The PM himself came into the room for a few moments, in a dressinggown, looking really very cheerful. I had very interesting talks with a great many.

Sunday, 26 December. Am sitting on the balcony in glorious sunshine overlooking the blue gulf, with the Zaghouan in the distance.

This jaundice is a most miserable disease.

27 December. At 0730 the battalion mounted a guard of honour and lined the route away from the white house, and $\mathrm{Mr}$ Churchill and party left. He was dressed in RAF uniform, of which Mrs Churchill very sweetly fastened the belt for him. He carefully inspected the Guard, and then they drove off to our cheers. Mrs Churchill gave us a beaming smile as she passed.

So ended three exciting weeks at the hub of the Allied war machine.

\section{The aftermath of war}

In August 1945 I was posted to the medical directorate at Field-Marshal Montgomery's headquarters in Germany. I was allocated to the German (or Wehrmacht) section, perhaps because I could speak fluent German. My job (with one superior officer, Lieutenant-Colonel Hugh Sixsmith) was to run the whole of the captured German military medical service in the British Zone: hundreds of German military hospitals, with about half a million patients, thousands of German medical officers, nurses, and other staff, motor vehicles galore, about 20 hospital trains, and four hospital ships. Among the patients were thousands of sick and wounded prisoners of war, and we had to organise them into trainloads and repatriate them to Italy, Yugoslavia, or whatever was their country of origin.

In those days the badly damaged German railway network was

*Sir John Cunningham, later First Sea Lord. full of trains of displaced persons being transported home: Russians, Poles, Czechs-every nationality that had been under Hitlerite domination. They travelled in huge trains, often in $\underline{T}$ cattle trucks, always with branches of trees profusely decorating 3 the rolling stock. These branches with their green leaves were $\stackrel{\otimes}{\circ}$ some sort of symbol of freedom and rejoicing.

We worked a pretty long day at Headquarters 21 Army Group -0830 to 1830 with short breaks for lunch and tea-and a lot of my time was taken up in organising the repatriation of sick and wounded displaced persons, and the repatriation of German Wehrmacht patients from other countries (even as far away as Canada) to the British Zone of Germany.

\section{Travel on an ambulance train}

I began to be concerned about the slowness of this repatriation, and decided to travel on one of the ambulance trains to Italy to inspect the arrangements at first hand. The officer commanding the train (No 1102) was a young RAMC officer; the doctors and $\infty$ nursing orderlies were all Germans; and the patients were all $\dot{\sigma}$ Italians, many extremely ill with severely infected wounds, advanced phthisis, etc. My diary records:

10 September 1945. The journey encountered one delay after another. A wagon slipped off the rails at Oeventrop, the $ᄋ$ normal route was closed, and from Hamm we were routed to Hannover. . . . We went through the famous marshalling-yards $\mathcal{O}$ at Hamm, and I met that almost legendary personage, the stationmaster of Hamm. . . .

12 September. Our progress was slow and wearisome through the day. I visited the lying coaches after lunch, where are several extremely ill tuberculous patients. Indeed, one of them was dead when we reached him.

13 September. Woke up at Nürnberg. We had made very slow progress in the night. We made even worse progress during the day and by evening had only reached Augsburg. From here the train was routed via Ulm, and so I decided to leave it. . . . I said goodbye to the Chefarzt and to Lieutenant Tizard, and stood on the platform as the train steamed out ... all the German crew drew themselves up stiffly to attention as they passed me. Meanwhile the Italians waved and smiled.

I put in a report to my chief, the director of medical services, Major-General Sir Edward Phillips, and he intervened at top level to get a higher priority for these ambulance trains.

\section{Trial of Belsen guards}

On a journey to Hamburg I called in at the trial of the Belsen guards.

25 September. The court house and surroundings were impressive, with many military. police, floodlights, loudspeakers, N

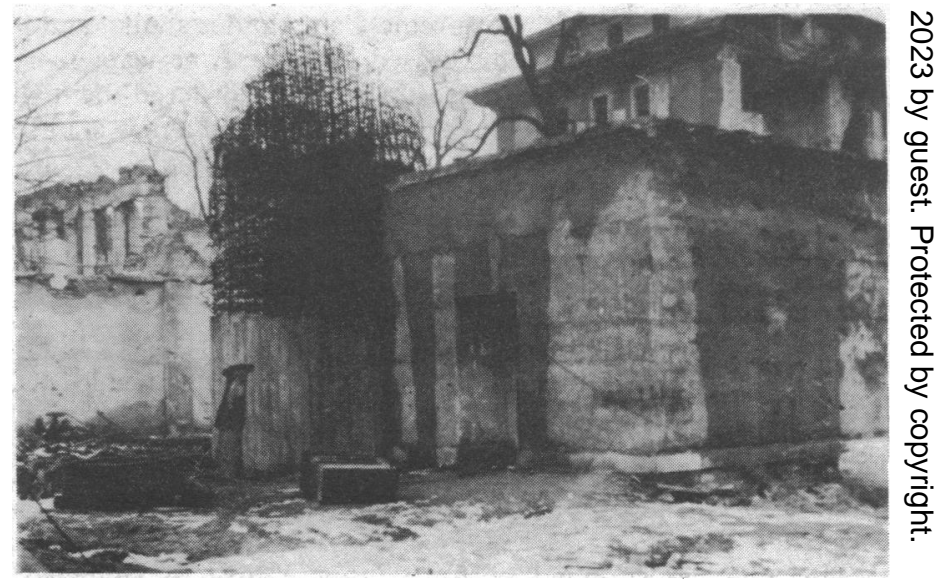

FIG 2-Door of the Führerbunker, Berlin, March 1946. 


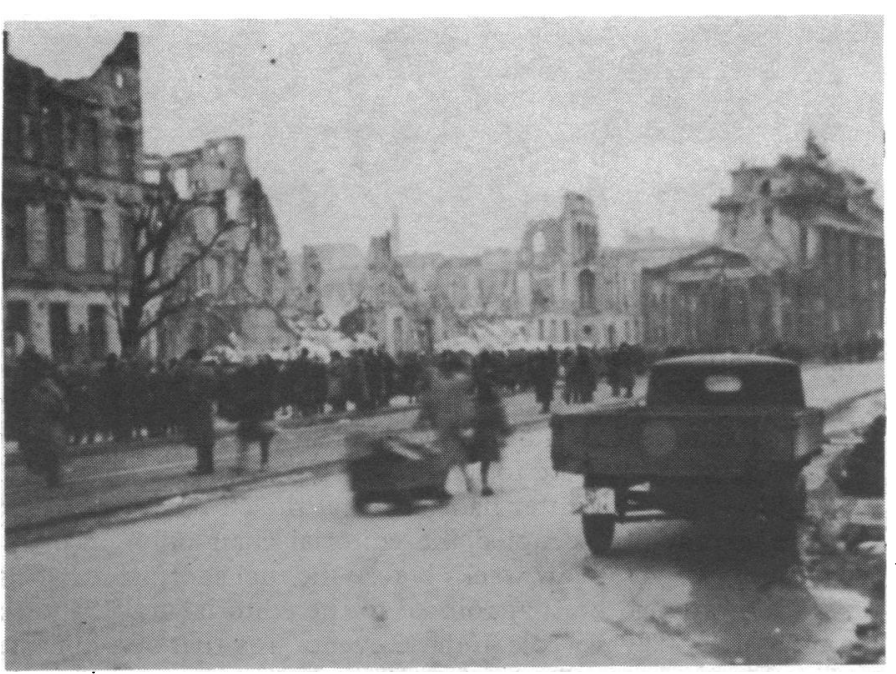

FIG 3-Black Market queue at Brandenburger Tor, Berlin, March 1946.

public galleries, press galleries, and so forth. The Bench were most impressive-a major-general and a brigadier in service dress, wearing their caps, three other officers, and a judge from England in a wig. ... . The prisoners in the dock were one of the most revolting sights I have ever seen. Out of the 40 odd, two only showed any trace of finer features denoting civilised intelligence. These two were Kramer [who had been the camp commandant] and Klein, the principal culprits. Out of the remainder, about eight were obvious sadists, with wicked hard cruel faces, and the other 30 were sub-human ... . without any sign of character or intelligence. . . . Irma Grese is plainly one of the sadists, with one of the wickedest hardest faces I have ever seen.

Later I was offered the task of being the medical officer on duty at the hanging of the Belsen criminals, but I was also required at a conference in Paris and opted for that.

4 December 1945. This afternoon I accompanied the DDMS, Colonel John Douglas, to a high level conference at Bad Oeynhausen ... there were representatives from all corps districts, Control Commission, Navy, RAF, and various other branches of this headquarters. The urgent-very urgentbusiness arose out of the fact that the Soviet Government has complained that Britain has not carried out the Potsdam agreements in her zone, and has preserved parts of the German Services including certain headquarters. The Russians of course think that we intend to attack them with these Germans. This is absolute nonsense, but the Americans and French also joined in the hue and cry and therefore the commander in chief agreed to demobilise at once all our disarmed Germans, including the odd 90000 in hospital. This conference was called in a great hurry to lay on this great operation.

\section{Berlin in 1946}

Early in 1946 I was sent on a mission to Berlin.

8 March. Berlin is an amazing sight. About $80 \%$ of all the buildings seem to be damaged or destroyed. The devastation in the Tiergarten and thereabouts is appalling. One sees lots of Russians wandering about, a few French and Americans, and of course a lot of British in our sector....

9 March. Visited Hitler's Chancellery (fig 1), a huge wreck of former gaudy, vulgar magnificence. Tinsel glory in ruins. Walked about the garden and inspected as much as we could of the famous Führerbunker (fig 2), and saw the spot where Hitler's and Eva Braun's bodies are supposed to have been burnt. Drove down the Unter den Linden, then to Alexanderplatz, then past the Russian Kommandatura. Drove round the seething black market on the edge of the Tiergarten (fig 3), then down to Potsdamer
Platz and Kurfürstendamm. Everywhere destruction and sordid ruins, human and material (fig 4).

The next day I went to call on an old friend of my father, the famous surgeon Sauerbruch. But first I encountered a young Rumanian conductor who was destined to become internationally famous in the world of music. Here is what I wrote that night:

10 March. David drove us down to the Theater des Westens in Kantstrasse, where Lilias and I heard a wonderful concert by the Berlin Philharmonic Orchestra, conducted by Sergiu Celibidache. ... At 1730 I called on Professor Sauerbruch. I found him and his young wife well dressed and luxuriously installed, apparently with plenty of food and cigarettes. (He is very useful to the Russians.) We had a long and interesting talk, out of which the following points emerge: (1) Sauerbruch denies that he was ever Hitler's surgeon, but he is proud of having been Hindenburg's surgeon, and claims to have been consulted in the illness of King George V. (2) He denies that he was ever a Nazi, but of course knew personally Hitler and all the top-ranking Nazis. He says Hitler was a hysteric with a mesmeric power over other people, especially women. (3) ... (4) He has many dealings with the high-ranking Russians, and says they have a high respect for England but no love for her. (5) He admits that many Nazis were criminals and should be punished, but in general he thinks the denazification is much too drastic and is punishing a lot of innocent people. (6) He says that when he heard stories about the concentration camps (before the war) he simply did not believe them, they seemed so unbelievable. (This I can understand.) (7) He thinks that Berlin may be largely rebuilt in 10 years! (His wife said 100.) He was clearly delighted that I had called, sent many kind messages to Papa, and accompanied me to the garden gate, where we shook hands warmly.

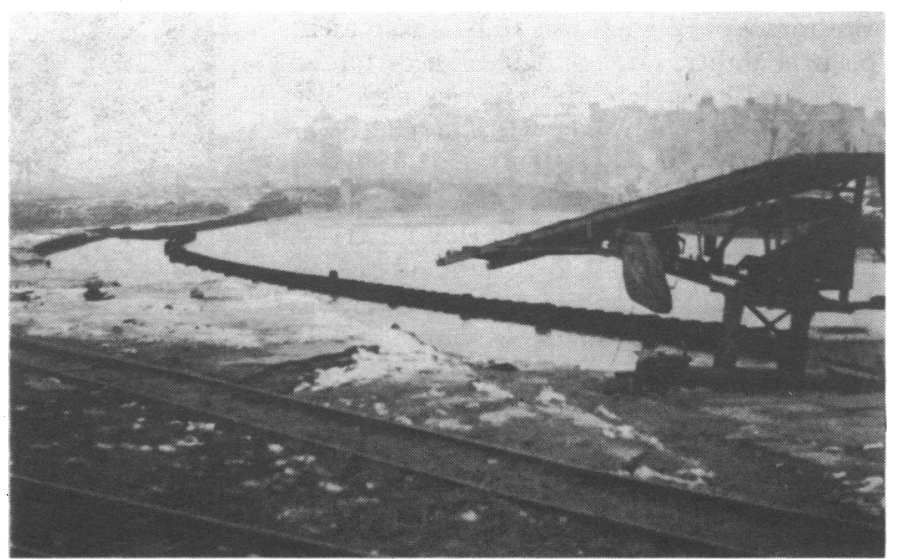

FIG 4-Looking across the Spree behind the Reichstag, Berlin, March 1946.

My diary of these times contains many other interesting things. I will finish by quoting:

Sunday, 31 March. The Government's National Health Bill has been laid before Parliament. I am waiting to see the reactions to it.

Russia has behaved very badly at UNO, trying by every means in her power to prevent Persia's complaint [that Kussia was continuing to occupy part of Persia] from being heard.

The Canadian spy trial shows that a lot of Communists or nearCommunists gave away secret information to Russia.

Plus ça change, plus c'est la même chose!

The photographs taken by Junior Commander Lilias Tomlinson, ATS, now Mrs Grey-Turner.

(Accepted 29 April 1980)

mo

\)

$\ddot{\vec{\Rightarrow}}$

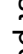

要

के

$\overrightarrow{0}$

$\overrightarrow{\vec{\omega}}$ 